\title{
Ethical and Moral Issues for Doing Fieldwork with Indigenous Peoples
}

\author{
David A. Hough \\ Customary Law and Language Commission, Republic of the Marshall Islands
}

Copyright $\subset 2017$ by authors, all rights reserved. Authors agree that this article remains permanently open access under the terms of the Creative Commons Attribution License 4.0 International License

\begin{abstract}
Based on more than 40 years of work with Indigenous peoples, but as a non-Indigenous linguist and educator myself, I ask in this paper what I believe to be some very crucial questions about the ethical responsibilities of non-Indigenous individuals - including those in the tourist industry - working in Indigenous communities. I begin the paper with an introduction of the sociohistorical conditions of $19^{\text {th }}$ century colonialism and how this shaped academic research on Indigenous peoples. During this period, anthropologists and linguists began to document the "primitive Other" as part of a project which became known as the science of race. While anthropological research supported colonization through ethnographic description, which portrayed Indigenous peoples through the lens of Eurocentric "Civilization," linguists were largely responsible for documenting Indigenous languages, often for the purpose of translating the bible in support of the Christianizing mission. Later they became occupied with cataloguing these same languages and cultures - now mysteriously "dying" for the sake of academic and intellectual posterity. Following this sociohistorical critique, I look at how the legacy of researching the "Other" has continued in areas from academia and development schemes to tourism - and why Indigenous values and cultures continue to be denigrated and co-opted. Here, I argue that as outsiders we must learn how to privilege Indigenous cultures. I conclude the paper with a discussion of what this might mean in terms of working toward a code of ethics for non-Native researchers, which truly privileges Indigenous voices.
\end{abstract}

Keywords Decolonization, Fieldwork Ethics, Indigenous Peoples

\section{Introduction}

My own background is that of a working class White Jewish-American who grew up in New York during the 1950 s and 1960s - a period of great activism which questioned the very foundations of a society we had been taught to believe in, where we sought to transform the racist and genocidal history that we were part of. My work with Indigenous peoples comes out of this history but is additionally informed by a moral conviction ${ }^{1}$ in their right to maintain and further develop their languages and cultures. These are deeply heartfelt and soul-searching issues which come from much reflection and at times even trauma over what we can and should do when working with Indigenous peoples - or whether we as outsiders from First World countries even have the right to embark on such endeavors. As a non-Indigenous person, I can only lend support. I cannot lead. But I also have the responsibility to be honest about my beliefs, and act on them where possible.

\section{Some Historical Background}

In the late $19^{\text {th }}$ Century - at the height of Euro-American colonialist expansion where genocide and plunder were euphemized as “The White Man's Burden," it was prevailing canon that Whites - by virtue of their self-proclaimed racial and cultural superiority - had the right to go anywhere, investigate anything and take from anyone. Part of this right was attributed to what was seen as the White man's innate sense of curiosity. Racial superiority, combined with curiosity and ambition were thought to be the cornerstones of the "civilizing" mandate. In the US, this was often termed "Manifest Destiny". Today it goes by the name "American exceptionalism" and is alternatively known worldwide as "globalization," "development," "the free market economy," and "the rule of law".

Science was also seen as the possession of an enlightened White population. Its roots are still attributed to such late $16^{\text {th }}$ and early $17^{\text {th }}$ century scholars as Francis Bacon - the reputed father of scientific method. Occasionally, references

1 I use "moral" here in the general and largely universalized Western Judeo-Christian sense of the term. From an Indigenous perspective, however, a more appropriate term might be "relational accountability," which binds us to all our Cosmic relations. (see Shawn Wilson, an Oposkwayak Cree scholar, 2008, for an elaboration of this). 
about scientific investigation and discovery go back to Ancient Greece an Egypt. ${ }^{2}$ Rarely, however, is credit given to non-European contributions to science - ranging from India and China to Indigenous knowledge systems worldwide. This Eurocentric worldview reduces all knowledge to a limited set of anthropomorphic research methods based on empiricism. It also denies that Indigenous science exists (or, at least, that it is real science).

David Peat (2004), a British physicist, criticizes the narrowness of empirical method by noting how according to this Eurocentric perspective, Indigenous peoples “don't have science in the real sense of the word. They don't have an ordered system of investigation or rational theories of the universe as we do. Science is a specific and disciplined approach that was developed in the West." Jared Diamond (1999) points out in Guns, Germs and Steel, that the vast majority of European scientific knowledge was stolen from non-western societies. He argues that stolen knowledge combined with the genocidal spread of western diseases, is what enabled colonial domination (a.k.a., globalization). Sandy Grande, (2004), a Quechua scholar, adds that on Turtle Island, ${ }^{3}$ the relationship between the US government and American Indians can best be described "as one of exploitation - that is, the imposed extraction of labor and natural resources for capital gain."

Peat says that this process of exploitation by a dominant economic and political power produced a scientific worldview which has forced all other cultures into a single, uniform way of seeing. This denigrates Native cultures and ways of knowing: "When Western science claims to be speaking the truth, then, by implication, other peoples' truths become legends, superstitions, and fairy stories. A dominant society denies the authenticity of other peoples' systems of knowledge and in this way strikes at the very heart of their cultures." P. 42.

Wallerstein (2004) notes that this Eurocentric worldview carried over into the development of the social sciences, which grew out of a late $18^{\text {th }}$ century divorce of the "pure sciences" from philosophy. ${ }^{4}$ Philosophy then divided into various sub-disciplines known under the general rubric of the Humanities or Arts and Letters. A further split occurred when some within the Humanities identified their scholarship more with empirical methodologies.

The first was history. Although historical enquiry goes back thousands of years, beginning in the $19^{\text {th }}$ century a new approach known as historiography attempted to make the discipline "scientific" by limiting its scope to the study of written records from the past that documented contemporaneous events and could then be archived. Thus,

2 Although Egypt is on the African continent, many US schoolbooks to this day brightly color Egypt on maps which highlight trade links to Europe across the Mediterranean, while separating it from the rest of Africa, which is colored gray.

3 Turtle Island is the term many Indigenous people use to refer to The Americas.

4 About the only remnant of the medieval European tradition linking science with philosophy is in the granting of doctor of philosophy degrees in a wide range of disciplines. written accounts by Europeans regarding their "discovery" of the "New World" could be included in the historical record, but oral accounts from Native peoples about their own past could not. Native peoples, in other words, had no history. This greatly reduced the scope of history to the documentation of evolving European nation states - all of which were Christian, had writing systems and claimed cultural links to the "high civilizations" of ancient Greece and Rome. ${ }^{5}$

One result of this narrow compartmentalization of history was the proliferation of other disciplines - also based on empirical method - which have come to be known as the social sciences. The first three were economics, sociology and political science. Anthropology was the fourth. As $19^{\text {th }}$ century European nations imposed their domination over the rest of the world, scientific interest shifted toward more ethnographic endeavors (Sorenson 1992). This allowed for the creation of what Willinsky (1998) describes as a "science of race," which was used to justify domination, theft of land, slavery and genocide. Anthropology thus became a new way to study Indigenous peoples under colonial control for the purpose of both further exploiting them and at the same time rationalizing that exploitation. Once their primitiveness and racial inferiority had been "scientifically proven," the issue of their "real" history had to be addressed. Since Indigenous peoples had no history, anthropology expanded its area of study into archeology so that researchers could literally dig up the Native past. More often than not, one of the aims of this type of archeological research was to de-legitimatize Indigenous narratives of their own past, including land tenure claims - and thus further expropriate land and natural resources. ${ }^{7}$

\subsection{The Legacy of Academic Imperialism Today}

This racist legacy still haunts us today. As linguists, anthropologists and other outside experts, we continue to view Native peoples as objects of study. We continue to embark on Indiana Jones-like adventures anywhere across the globe to investigate Native peoples, document their customs and languages, and to collect their tools, artifacts and even their bones. ${ }^{8}$ More recently, blood samples for

5 Non-Christian peoples with literate traditions from such places as China, India, Persia and the Arab world were seen as ancient "high civilizations" which were frozen in time and thus also largely excluded from the scientific progress of history. Studying these cultures required special philological skills acquired by western specialists known as Orientalists.

$619^{\text {th }}$ century American anthropological studies actually listed Blacks at the bottom, with American Indians slightly above Mexicans but below Chinese and Japanese.

7 Based on this paradigm archeologists still announce that bones found at a particular site really belonged to some long extinct prehistoric tribe and that they are unrelated to the current Native inhabitants, whom these "experts" claim migrated much later (in some cases after the beginning of colonization). This combined misuse of archeology and exclusion of Native accounts of their own past to tell official history allows for further exploitation of Indigenous land and resources.

8 Skeletal remains have long been a major issue of contention. Although many remains have been repatriated, many more have not - and in some cases, they continue to be taken. 
DNA testing have become a popular collector's item. These documents, test samples and artifacts continue to be carted back to institutions of higher learning, museums, libraries and research centers which are almost always managed by non-Native specialists charged with categorizing and cataloging them. Rarely are Native peoples part of the process beyond the most rudimentary, non-managerial roles. ${ }^{9}$

As linguists, we often claim that our interest in Indigenous languages is to document them for posterity sake before they die of natural causes. According to this scenario, people willingly give up their heritage language in order to help themselves and their children succeed in a globalized job market dominated by colonizer languages. Lenore Grenoble and Lindsay Whaley (1998), for example, claim "The fundamental cause for the disappearance of human language is well known. Speakers abandon their native language where use of that language is no longer advantageous to them." (p. 36). However, as I and others have written (Hough, Thapa-Magar and Yonjan-Tamang 2009), "Problems caused by the devaluation of one's mother tongue are endemic to Indigenous communities worldwide. They are not voluntary but are brought about by the domination of one language over another." Tove Skutnabb-Kangas (1999), an internationally renowned linguistic human rights scholar, writes: "...if people are forced to shift their languages in order to gain economic benefits of the kind which are in fact bare necessities for basic survival, this is a violation of not only their economic human rights but also their linguistic human rights." P. 214.

The results among Indigenous peoples in terms of human psychology range from feelings of inferiority, humiliation and self-hate to outright denial of one's culture and heritage. Here, it could be argued that denying children the right to learn in their mother tongue is a form of linguistic genocide. (See Dunbar and Skutnabb-Kangas 2008 UNPFII expert paper for a thorough discussion of this issue).

As linguists, we also often claim our documentation can help to preserve endangered languages but the results of our research rarely get back to the communities they are supposedly intended to serve - or, at least not in any usable form. One significant exception is an initiative being carried out in the Department of Linguistics at MIT, under work started by Wampanoag Native scholar Jessie Baird ${ }^{10}$ with the late Kenneth Hale (See Meyer and Alvarado, 2010; pp. 48-49 for a discussion of this by Noam Chomsky). Beyond

9 Managerial control of museums, libraries and archives has been an ongoing area of Indigenous struggle. In response to this, the Smithsonian National Museum of the American Indian opened in 2004 under Native American directorship. Nevertheless, it continues to come under criticism from Indigenous communities.

10 The Wôpanâak Language Reclamation Project began in 1993 under the direction of Jessie 'little doc' Baird who earned a Masters Degree in Algonquian Linguistics from MIT in 2000. The project aims to return fluency to the Wampanoag Nation as a principal means of expression. It is the first American Indian language to reclaim a language with no living speakers. that, however, the most frequent type of material that gets back to local communities is in support of the ongoing Christianizing mission - another legacy of colonization. Here, groups such as the Summer Institute of Linguistics and related organizations like the Wycliffe Bible Translation Foundation, combine linguistic documentation with missionary work.

It should be of no surprise, then, to find that linguists, anthropologists - and increasingly social workers, health specialists, ecotourism experts and development planners are not high on many Native peoples' respect lists. In fact, we are occasionally even asked to quit our projects and leave. Deloria (1988, p. 95) gives an account of one such incident where the Chairman of the Red Lake Chippewa tribe in Minnesota had anthropologists escorted from his reservation.

\subsection{Towards a Code of Ethics}

All of this suggests that, at the bare minimum, linguists, anthropologists and other non-Native researchers need to do some deep soul searching before even thinking about embarking on research and other projects in Indigenous communities. We need, among other things, to consider whose interests our research privileges, what gets studied and whose work gets published (Martin, 1994), where our funding comes from, how our grants may compete with funding for Indigenous initiatives, and how we can begin to repair the damage we have helped to create.

One way to redress some of this is to prioritize working with Indigenous peoples in bottom-up community-based initiatives, which support their agendas. This means seeing Indigenous communities as locations of struggle and survivance, where non-Native scholars can support Indigenous efforts to overcome over 500 years of domination and exploitation. Deloria (1988) makes the following proposal: "I would advocate a policy to be adopted by Indian tribes which would soon clarify the respective roles of anthropologists and tribes. Each anthro desiring to study a tribe should be made to apply to the tribal council for permission to do his study. He would be given such permission only if he raised as a contribution to the tribal budget an amount of money equal to the amount he proposed to spend in his study. Anthropologists would thus become productive members of Indian society instead of ideological vultures." P. 95.

Another way might be for all projects to come directly from Indigenous communities with funding controlled by them. Rather than outside experts getting to pick our own topics of research, I believe we should only become involved when asked - and then, only as advisors. All decisions about project funding, the appropriate methodology, and how the results are to be used, must be in the hands of the Indigenous communities. Unfortunately, this is almost never the case. Instead, it seems that the right of non-Native scholars and experts to go anywhere, investigate anything, and take from anyone continues unabated. 
The following is a brief compilation of some things Indigenous and minority activists have demanded that we as outside experts need to respect. It is offered here as a working list of concerns that might eventually go into a set of ethical guidelines for outsiders involved with Indigenous peoples.

\section{Linguistic and professional elitism and the need to "de-professionalize"}

Move away from the Western "scientific" paradigm. Critically examine our received academic, professional \& educational standards. Give back from a perspective of White guilt over the ongoing legacy of dominance and privilege. Stop doing research; become an activist. Understand how the glass ceiling ${ }^{11}$ keeps Indigenous people out of academia and the professions.

\section{Stop helping to create or exacerbate dependencies}

Develop a critical understanding of globalization. Stop telling Indigenous and minority peoples how to "fix" problems that the colonizing world has created, and stop demanding that they use Western top-down models in doing so. These models kill Indigenous democratic practices. Understand that Indigenous and minority peoples are not passive. Learn to listen and privilege their voices. Understand how minds are colonized and take steps to overcome that. Understand Indigenous tradition as scientific methodology.

\section{Stop Co-Opting}

Stop stealing Indigenous knowledge and cultural artifacts. Stop marketing Indigenous art, music, science, spirituality, tourism, etc. Critically scrutinize organizations claiming to promote fair trade, ecotourism, the environment, nature, etc. Work to protect Indigenous IPRs (Intellectual Property Rights). Stop DNA and other biological research among Indigenous peoples and their environments.

\section{Do not lead but walk with}

All projects should be bottom-up, not top-down. Stop "helping." Empowerment means community control and ownership based on traditional values, epistemologies, methodologies and metaphysics. Critically understand and use White privilege correctly. When not understanding Indigenous perspectives and teachings, accept them at face value. Properly contextualized, answers will come later. Understand that issues of Indigenous land rights cannot be separated from human rights, or from research initiatives.

\section{Some Non-concluding Remarks}

The legacy of genocide and colonization is still very much with us. Only the names have changed. Now going under the rubric of globalization, development, education, job creation, ecotourism, environmental sustainability, health care, substance abuse and domestic violence interventions, etc., they serve to do little more than further steal Indigenous lands, culture, language, knowledge and sovereignty - and enhance profits for the First World. Those who wish to work in Indigenous communities must be willing to come forward - not as leaders - but as allies in the struggle for Indigenous human rights.

\section{REFERENCES}

[1] Deloria, Vine Jr. (1988). Custer Died for Your Sins. Norman: University of Oklahoma Press, P. 95.

[2] Diamond, Jared (1999). Guns, Germs and Steel: The Fates of Human Societies. New York: W.W. Norton \& Company.

[3] Dunbar, Robert \& Skutnabb-Kangas, Tove (2004). Indigenous Children and Violations of the Right to Education. Expert paper written for the United Nations Permanent Forum on Indigenous Issues (UNPFII).

[4] Grande, Sandy (2004). Red Pedagogy: Native American Social and Political Thought. Lanham: Rowman \& Littlefield Publishers, Pp. 26-27

[5] Grenoble, Lenore A. \& Whaley, Lindsay J. (Eds.) (1998). Endangered Languages: Current issues and future prospects. Cambridge: Cambridge University Press, P. 36.

[6] Hough, David A. (2009). Setting the Groundwork for a Critical Sociohistorical Approach to Intercultural Communication. Memoirs of Shonan Institute of Technology, 43/1, 9-107.

[7] Martin, J. (1994). Intercultural Communication: A Unifying Concept for International Education. In G. Allen (Ed.), Learning Across Cultures. NAFSA: Association of International Educators, Pp. 9-29.

[8] Peat, F. David (2002). Blackfoot Physics. Boston: Weiser Books, P. xii, P. 42.

[9] Sorenson, M.P.K. (1992). Manifest Destiny: The Polynesian Society over 100 years. Auckland: The Polynesian Society.

[10] Wallerstein, Immanuel (2004). World-Systems Analysis - An Introduction. Durham: Duke University Pres, Pp. 2-7.

[11] Willinsky, John (1998). Learning to Divide the World: Education at Empire's End. Minneapolis: University of Minnesota Press, P. 76.

[12] Wilson, Shawn (2008). Research is Ceremony: Indigenous Research Methods. Halifax; Fernwood Publishing, Pp. 97-125. 